This item was submitted to Loughborough's Research Repository by the author.

Items in Figshare are protected by copyright, with all rights reserved, unless otherwise indicated.

\title{
Rationales and practices for dynamic stakeholder engagement and disengagement. Evidence from dementia-friendly health and social care environments
}

\section{PLEASE CITE THE PUBLISHED VERSION}

https://doi.org/10.1080/01446193.2019.1679383

\section{PUBLISHER}

Taylor and Francis

\section{VERSION}

AM (Accepted Manuscript)

\section{PUBLISHER STATEMENT}

This is an Accepted Manuscript of an article published by Taylor \& Francis in Construction Management and Economics on 21 Oct 2019, available online: https://doi.org/10.1080/01446193.2019.1679383

\section{LICENCE}

CC BY-NC-ND 4.0

\section{REPOSITORY RECORD}

Pascale, F, Efthimia Pantzartzis, I Krystallis, and Andrew Price. 2019. "Rationales and Practices for Dynamic Stakeholder Engagement and Disengagement. Evidence from Dementia-friendly Health and Social Care Environments". Loughborough University. https://hdl.handle.net/2134/13713250. 


\title{
Rationales and practices for dynamic stakeholder engagement and disengagement. Evidence from dementia-friendly health and social care environments
}

\author{
Federica Pascale ${ }^{\mathrm{a}}$, Efthimia Pantzartzis ${ }^{\mathrm{b}}$, Ilias Krystallis ${ }^{\mathrm{c}}$, Andrew D. F. Price \\ ${ }^{a}$ School of Engineering and the Built Environment, Faculty of Science and \\ Engineering, Anglia Ruskin University, Chelmsford, UK; ${ }^{b}$ School of Civil and \\ Building Engineering, Loughborough University, Loughborough, UK; ${ }^{\mathrm{c}}$ The Bartlett \\ School of Construction \& Project Management, University College London, London, \\ UK.
}

\begin{abstract}
Latest developments in stakeholder management literature focus on dynamic stakeholder engagement and disengagement practices, and how these are facilitated towards reaching systemic outcomes. However, limited evidence support that this network-level approach can positively influence project success. The paper analyses this issue by considering the practices (how and when), rationales (why) and outcomes (so what) that evolve in the dynamic management of external stakeholders in dementiafriendly environments. This is a crucial area to explore as the ageing population and rising dementia prevalence has increased the need to engage external stakeholders, such as people living with dementia, to develop dementia-friendly health and social environments. The empirical study of the 2013/14 Department of Health National Dementia Capital Investment Programme involved a statistical and qualitative analysis of 98 pilot projects' final lessons learnt reports. The analysis advances the dynamic process of timely engaging and disengaging external stakeholders in a context not previously explored in the literature related to dementia-friendly environments. Eight recurring practices and six rationales, the latter characterised by their temporal dimension, are presented in a processual model of stakeholder management.
\end{abstract}

Keywords: Stakeholder engagement; stakeholder disengagement; practices; rationales; vulnerable groups; dementia-friendly environments. 


\section{Introduction}

Stakeholder management theory views projects as successful if they consider stakeholder needs and requirements through the process of stakeholder management (Cleland, 1986; Olander and Landin, 2005). Stakeholder engagement is described as the practices a project or organisation perform to involve stakeholders in the project activity in a positive way (Greenwood, 2007). In the case of construction projects, good management practice is to recognise that stakeholder salience may change over the course of a project lifecycle (Aaltonen et al., 2015), as they are characterised by uncertainty, dynamics and complexity (Aaltonen and Kujala, 2016). However, research on stakeholder engagement has not considered it as a dynamic and on-going process that needs longitudinal studies to be understood (Eskerod and Vaagaasar 2014). Despite literature offering methods for stakeholder engagement (Eskerod et al., 2015), it downplays how and when to engage external stakeholders in practice (Parmar et al., 2010) and why (Eskerod and Vaagaasar 2014); whilst it focuses mainly on explaining high-level concepts (Gulati et al., 2012). These are also described in different ways as collaboration, cooperation and coordination in case of large-scale projects (Tee et al., 2019); or collaboration, cooperation and containment (Dunham et al., 2006) based on the level of commitment a firm employs to manage different stakeholder communities.

There has been a shift for projects and organisations to improve social and environmental responsibility (Miles, 2012) by adopting a network-level approach, involving broad and heterogeneous networks of external stakeholders to create system-wide benefits (Muller, 2009). These include benefits for the network actors and overall value for the system (Meynhardt et al., 2016; Reypens et al., 2016). However, most studies regard a network-level approach as challenging and thus, it is believed to have a negative impact in reaching project objectives (Aaltonen and Kujala, 2010; Flyvbjerg, 2014; Eskerod et al., 2015). A recent study 
asserted that a dynamic interplay between engagement and disengagement practices can contribute to reaching systemic outcomes (Lehtinen et al., 2019). However, how to achieve systemic project outcomes through a balanced approach adopting timely engagement and disengagement practices is still under-explored (Lehtinen et al., 2019).

Following the afore-mentioned considerations, the following research question has been formulated: How and why do internal stakeholders engage and disengage external stakeholders during project lifecycle? To address the question, this research provides a detailed account of the practices (how and when) employed to engage and disengage stakeholders during project lifecycle, the rationales (why) and outcomes (so what) that evolve in the dynamic management of external stakeholders in the context of dementia-friendly environment. A processual model emerged from the analysis that explicates which practices enable internal stakeholders to effectively engage and disengage with external stakeholders considering the temporal dynamics of stakeholder management. This combination of engagement and disengagement practices helps stakeholders navigate the complex process of stakeholder management during a project lifecycle. In addition, the analysis reveals the rationales behind the dynamic process of such stakeholder management. Thus, how internal stakeholders can employ engagement and disengagement strategies and why they support successful project delivery is shown.

The data for the research were collected from the stakeholder management approaches adopted by 98 pilot projects during the 2013/14 Department of Health England's National Dementia Capital Investment Programme (NDCIP). Within this Programme, the Department of Health (DH) allocated $£ 50$ million for the design and retrofit of health and social care facilities for people living with dementia (LWD). The organisations leading the 
pilot projects ${ }^{1}$ were asked to define their plans to actively involve stakeholders during the projects' lifecycles and translate outputs and findings from engagement into design strategies, validation and dissemination. The NDCIP offered the opportunity to analyse stakeholder management longitudinally and corroborate findings from multiple projects within a Programme focused on dementia-friendly environments. This is a topical area for stakeholder management literature. Given today's ageing population (WHO, 2015) and increasing dementia prevalence (Larson et al., 2013), there is a pressing need to improve engagement with people LWD and related stakeholders, as the demand for dementia-friendly environments is rapidly growing $(\mathrm{DH}, 2013)$.

The present study makes the following contributions. First, it explicates that across the Programme, the pilots engaged and disengaged in a timely manner over time. Moreover, the practices present cyclical and recurring patterns across the projects' lifecycles and have served different rationales. The recurring character of the practices enabled the pilots to achieve economies of repetition. Second, six rationales were found across the projects' lifecycles, which explain the processual description of why pilots engaged and disengaged over time. Furthermore, unlike existing literature assumptions, this study suggests that a collaborative approach comprises intertwined engagement and disengagement practices, and mutual communication channels. It further demonstrates that large-scale dynamic engagement is possible, even with vulnerable groups, such as people LWD, by planning a plurality of practices able to suit the interests and the ability of different stakeholders. The overall contribution of this paper is providing a detailed account of the process of stakeholder engagement in the topical context of dementia-friendly environments, whilst shedding light to

\footnotetext{
${ }^{1}$ Throughout this paper, the term 'projects' will be used to refer to the pilot projects funded by the NDCIP, whilst the term 'pilots' will be used to refer to the organisations that delivered the projects.
} 
the temporal dimension of rationales for stakeholder engagement and disengagement, an area that is currently underexplored.

\section{Literature review}

\section{Contextual challenges for stakeholder engagement and disengagement in health and social care construction projects}

Stakeholder management literature suggests that project success is highly dependent on considering the needs, and requirements of project stakeholders (Aaltonen and Kujala, 2010; Eskerod and Huemann, 2014). As dementia literature asserts that people LWD are the most important stakeholder (Pantzartzis et. al., 2016), alongside other essential stakeholders such as family, friends, and caregivers (Hellström et al., 2007; Elliott et al., 2016), the needs and requirements of these stakeholders should be considered to ensure project success. However, examples of engagement of people LWD in construction projects are limited, and research in health and social care projects for people LWD has focused mainly on advancing design solutions (Fleming and Purandare, 2010; van Hoof and Verkerk 2013; Aarts et al., 2015).

A challenge for construction projects is their temporal dimension. This is often described as three phases (e.g. front-end/delivery/handover) and characterised by uncertainty, dynamics, and complexity, as stakeholder attributes and positions change over time across the project lifecycle (Aaltonen and Kujala, 2016). With new classes and configurations of stakeholders appearing in response to changing circumstances (Post et al., 2002), external stakeholders should be engaged continuously and systematically throughout the project (Aaltonen and Kujala, 2010). Lehtinen et al., (2019) emphasised that to achieve project systemic outcomes it is also important to timely disengage external stakeholders. However, limited research thus far has considered stakeholder engagement and disengagement as a dynamic process (Aaltonen and Sivonen, 2009; Vaagaasar, 2011; Eskerod and Vaagaasar, 
2014). Namely, research into engagement practices has "remained rather theoretical, static and distant to empirical data" (Lehtinen et al., 2019). It has also given more significance on the engagement of various stakeholders during the front-end phase (Jergeas et al., 2000; Collinge and Harty, 2014, Aaltonen et al., 2015) and delivery phase (Collinge, 2016), and paid less attention to the dynamic process of engagement and disengagement as the project unfolds (Eskerod and Vaagaasar 2014).

Moreover, research examples mainly yield results from megaprojects (Missonier and Loufrani-Fedida, 2014; Aaltonen et al., 2015; Lehtinen et al., 2019). This is because megaprojects provide excellent case studies due to their long schedules (Di Maddaloni and Davis, 2017) and the fact that they are composed of several phases, each one comprising different activities and objectives, and distinctive stakeholders and attributes (Windsor, 2010). Despite the rich context these projects offer, a review highlighted that the process of stakeholder engagement as being underdeveloped (Mok et al., 2015). Whilst this is justified by the higher changeability and flexibility state of stakeholder management taking place in the early phases, the long timespans (often more than 30 years) posit another factor why only a limited number of studies looked at stakeholder engagement through this lens.

\section{Rationales for stakeholder engagement and disengagement}

Project management literature emphasises traditional approaches to stakeholder management rather than engagement, which entails different rationales (Eskerod and Vaagaasar, 2014). For example, the instrumental approach sees stakeholder engagement as a way to influence stakeholders (Project Management Institute, 2013) to make them contribute to the project objectives (Eskerod and Vaagaasar, 2014). The rationale behind this approach is to prioritise the most salient stakeholder in a dyadic perspective aiming at firm level outcomes (Mitchell et al., 1997; Bourne and Walker, 2005; Olander and Landin, 2005). Conversely, recent 
research in business and marketing is shifting from management of stakeholders to a more collaborative engagement of stakeholder perspective (Meynhardt et al., 2016). This network perspective sees the views of stakeholders from different networks to be incorporated in a systemic approach towards value-creation at micro (e.g. customers), meso (e.g. lobbyists) and macro (e.g. public) level, rather than just the firm or dyadic perspective aiming at firm level outcomes (Meynhardt et al., 2016; Reypens et al., 2016). Some of the rationales for external stakeholder engagement behind the network approach are the importance of peripheral stakeholders in the development and diffusion of new ideas and innovations (AarikkaStenroos et al., 2017), and the distribution of power and creation of trust among stakeholders (Rampersad et al., 2010). Indeed, construction projects and organisations face increasing pressure to improve social and environmental responsibility (Miles, 2012), and create macrolevel outcomes. Rationales such as improvement of Quality of Life (QoL) and increase of economic sustainability while reducing the environmental impact (Bal et al., 2013), are becoming foundations for adoption of wide stakeholder engagement strategies (Aaltonen and Kujala, 2010). Conversely, in the management of projects perspective, the rationale for engagement is still described at micro-level as a balancing act between gainers and losers (Winch et al., 2007; Morris, 2013).

In addition, project management literature often views external stakeholders and their actions in negative and opposing terms (Chan and Oppong, 2017; Teo and Loosemore 2017; Di Maddaloni and Davis, 2018). These actions are mainly driven by stakeholder concerns about construction projects' long-term value achievement, and their impact on social, environmental, and economic sustainability (Chan and Oppong, 2017). This leads management teams to adopt disengagement strategies with external stakeholders, such as dismissal or concealment (Aaltonen et al., 2015). This is because they are driven by shortterm goals, such as budget, schedule and performance (Aaltonen and Kujala, 2010), and the 
need to reach key milestones (Flyvbjerg, 2014). Hence, literature has thus far described stakeholder disengagement mainly in negative terms. For example, stakeholder disengagement was described as a result of tensions between notions of place brand identity and brand identity of the stakeholders' own organisation (Casidy et al., 2019), or failure to address matters that were the prime concern of some stakeholders, resulting in trust issues (Jenkins, 2018). Recently, a study suggested overcoming the dichotomy of engagement or disengagement in favour to gradual but simultaneous use of both practices and proposed four rationales for engagement and disengagement practices from a systemic perspective: framing; legitimating; maintaining; and expanding (Lehtinen et al., 2019). However, as this study sheds new light to stakeholder management, more empirical studies are needed to unpack rationales for timely engagement and disengagement of stakeholders to achieve systemic outcomes.

\section{Practices as vehicles of timely engagement and disengagement}

Routines and activities that can be implemented to engage external stakeholders at practical and fine-grained level can be defined as practices (Lehtinen et al., 2019). Chinyio and Akintoye (2008) explained the need to use a combination of practices to engage with stakeholders successfully. Active dialogues have also been recognised as proactive practices to shift the opposing stakeholders into neutral ones (Aaltonen and Sivonen, 2009). In the healthcare context, Collinge and Harty (2014) reported a series of engagement practices in hospital projects during the front-end phase (including detailed pre-project meetings between staff groups, stakeholder consultation exercises and community engagement initiatives), but engagement practices during delivery and handover phases were not reported. Evidently, there is a sufficient body of work reporting stakeholder engagement practices at the project front-end (Edkins et al., 2013; Collinge and Harty, 2014; Aaltonen et al., 2015) compared to 
other project phases.

Eskerod and Vaagaasar (2014) gave an account of dynamic engagement practices project teams adopt to create trust longitudinally; it also reported disengagement strategies being adopted, especially in challenging moments. However, the practices presented are mainly formal (e.g. develop contracts). Yet, empirical and processual investigation on the practices for engagement and disengagement during the project lifecycle is still under debate in the literature. For example, whilst in the case of Eskerod and Vaagaasar (2014) the practices were partially planned and partially emergent to answer to changing stakeholder positions; in Lehtinen et al. (2019) they cycle back and forth between engagement end disengagement to achieve systemic outcomes. However, there is still limited empirical evidence in the literature about how engagement and disengagement practices co-exist in practice to bring this beneficial state to the system.

\section{Methodology}

\section{Case setting}

The data presented in this paper were collected during the 2013/14 DH England's NDCIP. The purpose was for the pilots and the DH to collaboratively improve health and social environments for people LWD and undertake an evaluation and fact-finding exercise to develop policy and guidance as to what constitutes high quality dementia-friendly environments. The NDCIP provided $£ 50 \mathrm{M}$ funding to the pilots as part of a two-phase Programme: Phase 1: selection of projects through tendering; and Phase 2: the delivery of the projects and evidence-based demonstration of impact. The size of the projects ranged from $£ 8,000$ to $£ 1.5$ million. The funding was made available to improve a diverse variety of care settings, including acute, teaching and general hospitals, care homes, day centres, respite centres. 


\section{Data collection}

To fulfil the purpose of the initiative, each pilot involved in the NDCIP was required to submit a 'final lessons learnt report' (i.e. self-reports) ${ }^{2}$ to convey at the end of the Programme what they had achieved and what wider differences the work had made to people LWD in their individual organisations. Self-reports can be used to assess characteristics that are defined to have stability, coherence, and generality across situations and to assess characteristics that are defined within situation and time parameters (Moskowitz, 1986). The pilots were also asked to document in detail various data relevant to their projects. In terms of stakeholder management, they were asked to report who were the stakeholders they engaged with, how they engaged, when and why across the projects' lifecycles. This approach to report data allowed to capture the longitudinal dynamic process of stakeholder management throughout the projects' lifecycles as adopted in the NDCIP.

The report template distinguished between three phases: front-end phase (i.e. during the preparation of the projects for tendering); delivery phase (i.e. while the projects were implemented); and handover phase (i.e. after the projects' completion and moving to operation). For this study, data were extracted from the reports of the 115 pilots. Ninety-nine reports were used for this study (85.2\% census); the remaining 17 reports, either were not returned on time (i.e. 12 months after securing funds), or the provided data were deemed insufficient for use and therefore excluded. The pilots were invited to respond to open-ended questions and closed-ended questions.

\section{Data analysis}

The reported data were analysed in three steps. In the first step, the data obtained from the 98

\footnotetext{
2 Throughout this paper, the term 'reports' will be used to refer to the final lessons learnt reports submitted by the pilots at the conclusion of the NDCIP.
} 
reports were structured in MS Excel. Each report was read, and data extracted before moving to the next report. All documented stakeholders and engagement events were inserted into a spreadsheet, under each pilot. A total of 1312 entries were recorded. From those 1312 entries, 306 distinct event types and 409 distinct stakeholders were identified. These were then aggregated into eleven stakeholder categories (Table 1) and eight practices (Table 2). To formulate these categories, existing literature was consulted, and a research team workshop was undertaken to brainstorm how each of the coded data was to be categorised. Stakeholders were aggregated into stakeholder categories based on their interest and status in the projects. For example, friends, families, visitors and carers were grouped into the same category because they share common actions and interests in the projects. Similarly, events with similar purpose were aggregated to formulate the engagement practices. For example, opening events (event type A) and garden parties (event type B) were grouped into the same practice (open days and visits practices).

In the second step, statistical tests (Field 2009) were performed to look for patterns in this large dataset, using MS Excel. For consistency, several processes took place before performing statistical tests, as such, data were categorised, edited and coded. Then descriptive statistical analysis was implemented to examine which practices the pilots facilitated the most across the projects' lifecycles; which practices mostly involved external stakeholders; and whether there were any stakeholder engagement differences among the three project phases. A significant difference could mean that practices engage in different ways across the projects' lifecycles so this should be considered when looking for patterns of engagement and disengagement in the dataset. No differences would mean that there was stability of stakeholder engagement and disengagement across the projects' lifecycles. Thus, a parametric analysis of variance (repeated measures ANOVA test) was also conducted. The 
repeated measures ANOVA test was selected to measure the effect of variance of withingroup practices and between-group practices.

In the third step, how external stakeholders were engaged and disengaged throughout the projects' lifecycles was theorised. The statistical findings from the previous step were used as a framework and the reports were re-read to ascribe each practice to the reasons of facilitation. Hence, another column was added in the datasheet explicating the reasons for facilitating each practice. These practices were then interpreted by adopting a narrative approach (Pentland, 1999). The outputs of step two provided answers regarding who was engaged, when, what type of engagement took place; whilst this additional set of data allowed looking for sequential patterns to provide the rationales of engagement. In the extraction sheet, narratives from the reports that would explicate the rationales for engagement and, where explicitly identified, the outcomes of engagement were reported. Illustrative quotations from the reports were included to ground the findings to the data. The above analysis enabled practices across the three project phases to be congregated into engagement and disengagement clusters. Figure 1 outlines the process and outputs of these three steps.

\section{Limitations}

There may be a certain degree of positioning bias from the authors of the reports. To minimise this, the report instrument consisted primarily of open-ended self-descriptions rather than closed-ended questions. Literature suggests this is a safe way to minimise respondent bias and gives the freedom to respondents to use any constructs they wish in describing certain phenomena (Paulhus and Vazire, 2007). In addition, there may be a certain degree of bias amongst the pilots since the completion of the projects spanned across the Programme. The pilots were able to engage with each other, as they deemed necessary, so it was not possible to control knowledge spill overs. To minimise such bias reflected in the 
reports, the pilots were asked to complete them at the end of the Programme, which means that the individual projects were completed by then, and the pilots could reflect on the overall experience without being influenced by the performance of the others.

\begin{tabular}{|c|}
\hline \multicolumn{2}{|c|}{ Step 1: Literature + Workshop } \\
\hline Stakeholder categories \\
\hline Step 2: Statistical tests \\
\hline Level of stakeholder engagement and practices employed across project phases \\
\hline Step 3: Findings from statistical tests + qualitative analysis \\
\hline Engagement and disengagement practices \\
\hline
\end{tabular}

Figure 1: Methodological steps and outputs of the analysis

\section{Findings from National Dementia Capital Investment Programme}

\section{Which stakeholder categories and engagement practices emerged from the Programme?}

There was an extensive range of stakeholders involved throughout the NDCIP, and different terminologies were used to describe the various stakeholder organisations, groups, and individuals. After reviewing the stakeholders being referred to by the pilots, 11 categories were identified and used to classify the stakeholders (Table 1). To enable the analysis, the 11 categories were further grouped into external and internal stakeholders. A total of 409 registered stakeholder entries were initially documented. These were grouped into 230 subcategories and finally aggregated into 11 categories. Table 1 presents the roles and responsibilities of each stakeholder category, the interest in engaging in the Programme and example types of stakeholders. 
Table 1: Stakeholder categories in the NDCIP

\begin{tabular}{|c|c|c|c|}
\hline $\begin{array}{c}\text { Stakeholder } \\
\text { Categories }\end{array}$ & $\begin{array}{c}\text { Roles and } \\
\text { Responsibilities }\end{array}$ & $\begin{array}{l}\text { Interests in the } \\
\text { engagement }\end{array}$ & $\begin{array}{c}\text { Stakeholder } \\
\text { types examples }\end{array}$ \\
\hline \multicolumn{4}{|c|}{ Internal stakeholders } \\
\hline Commissioners & $\begin{array}{l}\text { Projects delivery, monitoring } \\
\text { and reporting. }\end{array}$ & $\begin{array}{l}\text { To develop effective dementia- } \\
\text { friendly environments; } \\
\text { transform dementia care } \\
\text { delivery; improve } \\
\text { communication between care } \\
\text { providers; increase } \\
\text { empowerment in community } \\
\text { settings. }\end{array}$ & $\begin{array}{l}\text { Clinical } \\
\text { Commissioning } \\
\text { Groups, Dementia } \\
\text { Commissioners }\end{array}$ \\
\hline $\begin{array}{l}\text { Dementia expert } \\
\text { community }\end{array}$ & $\begin{array}{l}\text { Projects progress and impact } \\
\text { monitoring; data collection } \\
\text { and analysis; evidence and } \\
\text { lessons learnt gathering and } \\
\text { reporting. }\end{array}$ & $\begin{array}{l}\text { To contribute to research } \\
\text { advancement in the field of } \\
\text { health and social care } \\
\text { environments for people LWD. }\end{array}$ & $\begin{array}{l}\text { Academics, Subject } \\
\text { Experts }\end{array}$ \\
\hline $\begin{array}{l}\text { Supply chain } \\
\text { partners }\end{array}$ & $\begin{array}{l}\text { Technical support in all } \\
\text { Programme phases. }\end{array}$ & $\begin{array}{l}\text { To develop effective dementia- } \\
\text { friendly environments; share } \\
\text { technical knowledge and learn } \\
\text { how to support people LWD } \\
\text { independently in the wider } \\
\text { community. }\end{array}$ & $\begin{array}{l}\text { Consultants, } \\
\text { Contractors, } \\
\text { Equipment suppliers }\end{array}$ \\
\hline $\begin{array}{l}\text { Health and social } \\
\text { service providers }\end{array}$ & $\begin{array}{l}\text { Project delivery, monitoring } \\
\text { and reporting. }\end{array}$ & $\begin{array}{l}\text { To develop effective dementia- } \\
\text { friendly environments; and } \\
\text { organisational dementia } \\
\text { awareness; improve asset and } \\
\text { space utilisation. }\end{array}$ & $\begin{array}{l}\text { Community service } \\
\text { providers, Day-care } \\
\text { centres, Trusts }\end{array}$ \\
\hline Policy makers & $\begin{array}{l}\text { Programme funding } \\
\text { provision and surveillance. }\end{array}$ & $\begin{array}{l}\text { To achieve: capital gearing; } \\
\text { Value for Money (VfM) and } \\
\text { Return on Investment (RoI); } \\
\text { and long-term environmental, } \\
\text { economic and social impact. }\end{array}$ & $\begin{array}{l}\text { Department of } \\
\text { Health, Secretary of } \\
\text { State for Health }\end{array}$ \\
\hline \multicolumn{4}{|c|}{ External stakeholders } \\
\hline $\begin{array}{l}\text { Family, friends } \\
\text { and carers }\end{array}$ & $\begin{array}{l}\text { Knowledge sharing on the } \\
\text { needs of people LWD. }\end{array}$ & $\begin{array}{l}\text { To improve: QoL of family, } \\
\text { carers and people LWD; ability } \\
\text { to care; and attractiveness of } \\
\text { the environment. }\end{array}$ & $\begin{array}{l}\text { Relatives, Carers, } \\
\text { Friends }\end{array}$ \\
\hline $\begin{array}{l}\text { Local } \\
\text { communities }\end{array}$ & $\begin{array}{l}\text { Knowledge sharing and } \\
\text { transfer activities. }\end{array}$ & $\begin{array}{l}\text { To learn how to support people } \\
\text { LWD independently in the } \\
\text { wider community. }\end{array}$ & $\begin{array}{l}\text { Local businesses, } \\
\text { Local schools, } \\
\text { Communities }\end{array}$ \\
\hline $\begin{array}{l}\text { National } \\
\text { charitable } \\
\text { organisations }\end{array}$ & $\begin{array}{l}\text { Knowledge sharing and } \\
\text { support in the project } \\
\text { development. }\end{array}$ & $\begin{array}{l}\text { To spread the impact of the } \\
\text { NDCIP at national level } \\
\text { towards new policy and local } \\
\text { support networks development. }\end{array}$ & $\begin{array}{l}\text { Age UK, Alzheimer's } \\
\text { Society, Dementia } \\
\text { Action Alliance }\end{array}$ \\
\hline $\begin{array}{l}\text { People with } \\
\text { dementia }\end{array}$ & $\begin{array}{l}\text { Direct knowledge transfer on } \\
\text { the needs of people LWD }\end{array}$ & $\begin{array}{l}\text { To improve people LWD's } \\
\text { QoL }\end{array}$ & Residents, Patients \\
\hline Staff & $\begin{array}{l}\text { Knowledge transfer on the } \\
\text { requirements for medical and } \\
\text { care staff. }\end{array}$ & $\begin{array}{l}\text { To improve service delivery } \\
\text { through provision of specialised } \\
\text { dementia-friendly } \\
\text { environments. Improve } \\
\text { understanding people LWD's } \\
\text { needs. }\end{array}$ & $\begin{array}{l}\text { Network of } \\
\text { Caseworkers (e.g. } \\
\text { Dementia Advisors, } \\
\text { Nurses, Doctors), } \\
\text { Estates staff }\end{array}$ \\
\hline $\begin{array}{l}\text { Support network } \\
\text { and public }\end{array}$ & $\begin{array}{l}\text { Project development support } \\
\text { and cross-organisation } \\
\text { knowledge sharing. }\end{array}$ & $\begin{array}{l}\text { To improve dementia } \\
\text { awareness in community } \\
\text { settings; and enhance } \\
\text { knowledge. }\end{array}$ & $\begin{array}{l}\text { Dementia Support } \\
\text { Groups, Dementia } \\
\text { champions, Care } \\
\text { group boards, Public }\end{array}$ \\
\hline
\end{tabular}


The various engagements that occurred during the Programme were grouped into eight practices (Table 2). A total of 233 registered entries were initially documented. These were grouped into 101 subcategories and finally aggregated into 8 practices. Table 2 presents the purpose of each practice, representative event types and excerpts derived from the reports describing what the events did in practice. 


\begin{tabular}{|c|c|}
\hline Practices and purposes & Description/illustrative quote(s) \\
\hline $\begin{array}{l}\text { Dementia-friendly } \\
\text { environments knowledge } \\
\text { sharing and networking: to } \\
\text { create and maintain networks of } \\
\text { stakeholders to involve into the } \\
\text { planning and development of the } \\
\text { NDCIP. To share knowledge } \\
\text { gathered during the NDCIP on } \\
\text { effective dementia-friendly } \\
\text { interventions. }\end{array}$ & $\begin{array}{l}\text { Dementia day: "The Trust also held a dementia day with local organisations such as }[\ldots], \text { Age UK, British Legion, }[\ldots], \text { Cares, }[\ldots] \\
\text { and Music in Hospitals to gain knowledge and understanding of people with dementia and ensuring the environment being created } \\
\text { was suitable". } \\
\text { Memory lane event: "as part of National Dignity Day, the }[\ldots] \text { (an intermediate care facility) organised a 'memory lane' event which } \\
\text { proved invaluable in supporting the design principles of the project as well as wider engagement amongst clinical teams, the general } \\
\text { public, carers and voluntary sectors". } \\
\text { Listening event: "Two Listening Events were held with stakeholders prior to commencement to ensure that the stakeholders were } \\
\text { involved in the initial planning stages of the project". } \\
\text { Training programme: "This involvement provided them with the opportunity to increase awareness amongst staff whilst developing } \\
\text { and commissioning a two-day bespoke training programme for the multidisciplinary team". }\end{array}$ \\
\hline $\begin{array}{l}\text { areness: to } \\
\text { eness among } \\
\text { on dementia } \\
\text { on the impact of } \\
\text { adly environments }\end{array}$ & $\begin{array}{l}\text { Dementia Theatre: "The Project Team then held a Dementia Theatre [...] to over } 100 \text { people, which included an overview of the } \\
\text { works undertaken and attendees were from the local community, care providers and other NHS Trusts". } \\
\text { Workshop: "The Project held a local King's fund workshop in October } 2013 \text { to engage widely with stakeholders to ensure there was a } \\
\text { wide understanding of the impact of the environment on people with dementia. Over } 50 \text { people attended including carers, staff, [...]". } \\
\text { Feedback: "Throughout the process regular feedback and updates have been offered to the project Community Reference Group and } \\
\text { the Black and Minority Ethnic Forum. The groups' members have the role of disseminating the information to the countywide groups } \\
\text { and forums they represent". }\end{array}$ \\
\hline $\begin{array}{l}\text { lopment: to gather } \\
\text { ss ideas, collect } \\
\text { ghts and feedback } \\
\text { lders. To identify the } \\
\text { oject and inform } \\
\text { gn and development } \\
\text { he Programme }\end{array}$ & $\begin{array}{l}\text { Public exhibition: "The final designs were open to scrutiny and feedback through a public exhibition [...]. Visual displays of final } \\
\text { designs were held [...] in a busy corridor area as well as in an area }[\ldots] \text { close to the older person's wards. For each of these displays, a } \\
\text { feedback form was available to give people an opportunity to voice their opinions about the designs". } \\
\text { Workshop: "This initial workshop was held with patients, carers and community representatives and each undertook an assessment of } \\
\text { the current older person wards using the King's Fund ward assessment tool followed by an opportunity to give their input into the } \\
\text { initial designs". } \\
\text { Focus group: "A focus group was held with carers to discuss the environment providing valuable insights and feedback which we } \\
\text { have incorporated these into the project plan". } \\
\text { Consultation with people LWD: "Focus groups were not an appropriate way to consult residents with dementia about the [...] changes } \\
\text { because of their high levels of cognitive impairment and the potential for confusion. A fieldwork approach was used instead. Here, the } \\
\text { researcher joined residents in the care homes as they went about their day-to-day lives and routines in the areas that have been } \\
\text { developed under the [...] programme". } \\
\text { Experience-based Design: "Experience Based Design (EBD) was utilised to capture the valuable input service users can provide". } \\
\text { Consultation event: "[...] an event was arranged to consult, inform and involve members of the general public in the project. This } \\
\text { took place on [...] at a local community venue". }\end{array}$ \\
\hline $\begin{array}{l}\text { Inforr } \\
\text { views }\end{array}$ & $\begin{array}{l}\text { made to the project was by the Alzheimer's Society and [...] City Museum. The two stakeholders } \\
\text { their carers through memory cafés held by the Alzheimer's Society and trips were organised to }\end{array}$ \\
\hline
\end{tabular}


design development through

informal engagement.

Media exposure: to provide the wider community with update regarding the improvements of the built environments for people LWD.

Meetings: to further scope out projects aims and details and to monitor the progress and results of pilot projects through formally recorded meetings.

\section{Open days and visits: to} showcase models of the potential environmental changes and contribute to the evidence and

findings gathering exercise.

\section{Strategic, regional boards and}

groups: to share and discuss improvements in dementia care delivery; to monitor and evaluate progress against project

milestones.
Conversations: "[...] this was largely carried out by clinically based members of the project group. [...] On a more one to one basis plans were shared with relatives who had been through the 'Dementia journey' with a loved one".

"As part of our patient feedback policy, a PPI representative approaches patients with dementia and their carers and engages them in a conversation".

Newsletter: "[...] the wards put a regular column in the ward newsletter and photographs of the construction progress were displayed in the wards entrance lobbies".

Videos: "We have taken this opportunity to promote our project through: [...] producing a film on early onset dementia 'Still Here"" -

"A video was developed to show a timeline of the project and people can visualise the pre and post refurbishment".

Social Media: "[Externa stakeholders] have been able to follow the construction progress by accessing the Trust's Facebook page where regular photographs have been displayed".

Newspaper and radio: "A clear communication strategy to publicise the project work through engagement with newspapers, local radio and regular articles in the Council's own quarterly magazine".

Steering and project group meeting: "The project manager and team worked closely with representatives of a range of organisations including our main partner [...] and the voluntary, community and social enterprise sectors. These engagements were managed to deal with the majority of the formal business".

Meeting with third sector: "The Project Team held meetings with the Alzheimer's Society and provided them with the scope of works being undertaken, following the submission of the mood boards".

"The Trust runs an Open Day every year, so we took this opportunity to showcase a model of the potential environmental changes,

which stimulated some keen discussions, these were captured in the form of questionnaire's".

The third sector volunteer groups could "contribute in various creative ways i.e. music groups, arts and crafts and gardening".

Meeting with the Trust Board: "[...] the Project Manager has attended various Trust meetings to give updates on the project, with monthly reports being submitted to the Trust's Capital Project Programme Group". "A paper detailing the proposals was also presented" was presented to the Trust Board. "The ideas were presented to the Trust Board and the Care group board. This was particularly important given the logistics of building work on four different wards".

Dementia Strategy Board: With Councils and Boroughs, pilots discussed how "to deliver the in-patient pathway for NHS continuing care service to residents". 
Figure 2 presents the proportion of pilots reporting engagement with each of the 11 categories identified in Table 1. The Programme succeeded in engaging with external stakeholders, as most pilots reported engagement with family, friend and carers (89\%) and people LWD (90\%), as well as staff (77\%) during the projects' lifecycles. The pilots also engaged with various internal stakeholders, with most pilots reporting engagement with commissioners $(60 \%)$, followed by health and social service providers $(45 \%)$.

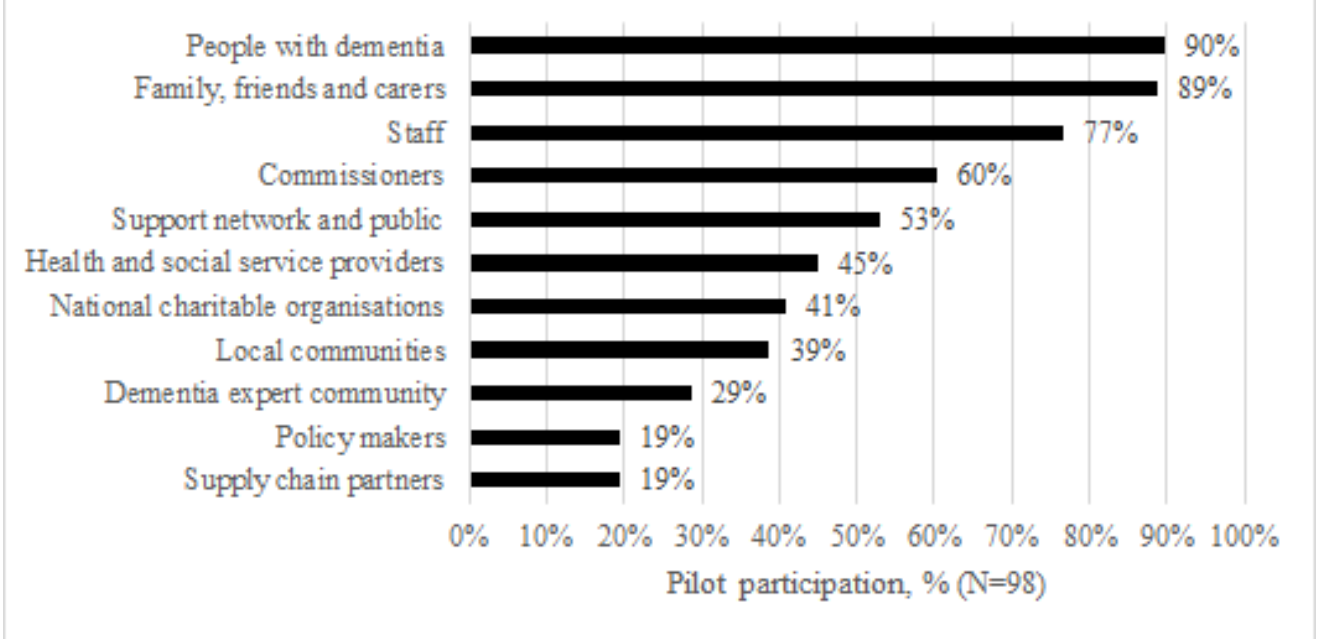

Figure 2: Percentage of pilots engaging with each stakeholder category in the NDCIP

The pilots used a range of practices to engage with stakeholders (Figure 3). Due to the nature of the Programme, $76 \%$ of the pilots engaged in design development engagement practices. At an equal high rate, the pilots reported implementing two more practices, meetings (62\%) and dementia knowledge and networking practices $(62 \%)$. The rest of the practices were not embraced by the majority of pilots, and analysis suggests that these could have been used in conjunction or as alternative practices to serve a specific rationale. 


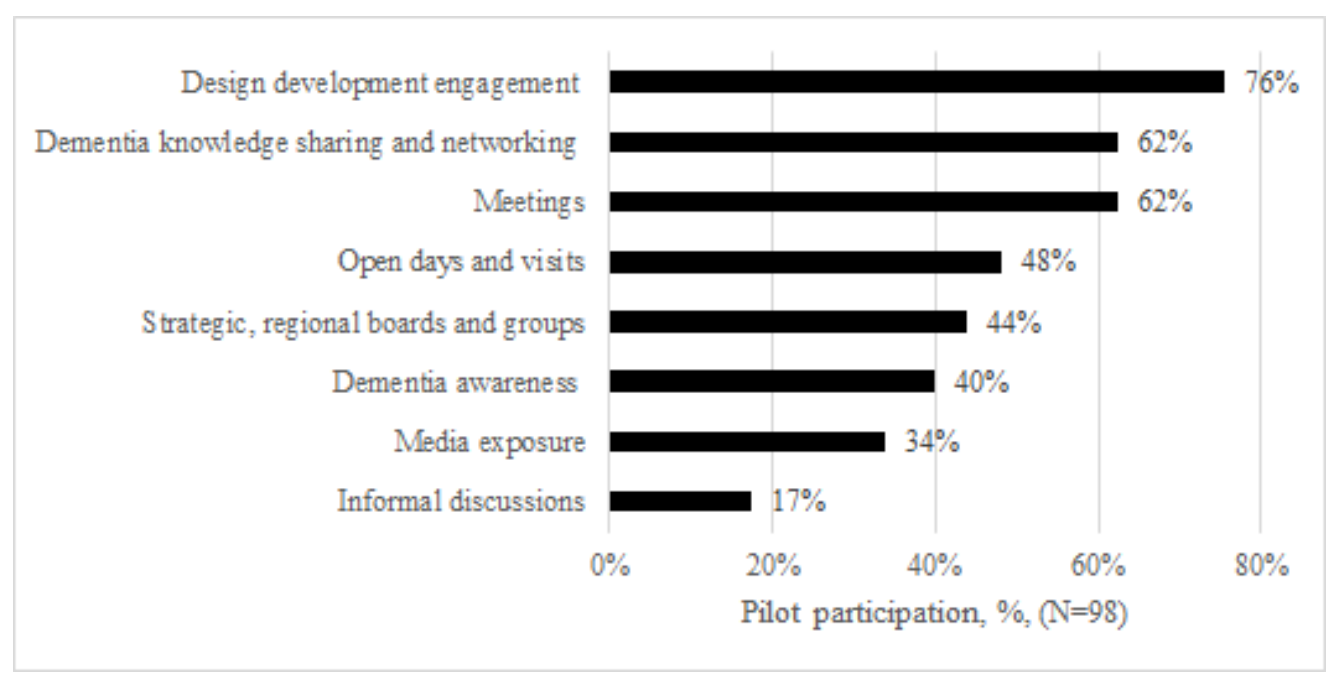

Figure 3: Percentage of pilots engaging with each practice in the NDCIP

\section{Which practices the pilots facilitated the most across the projects' lifecycle?}

After establishing that the pilots engaged both internal and external stakeholders, to a satisfactory degree through a variety of practices, it was tested which of the practices were facilitated the most across the projects' lifecycles. For this purpose, three snapshots of the projects' lifecycles were taken: front-end, delivery and handover. Figure 4 shows when these practices took place. Considering the front-end phase, two practices outperformed the rest. Half of the pilots implemented design development practices, with a decreasing trend as projects moved to completion. A similar pattern was observed for meeting practices, where $41 \%$ of the pilots implemented these in the front-end phase, with only $21 \%$ of the pilots reporting facilitation of these practices at handover phase. Strategic, regional boards and groups were the third practices with $27 \%$ of the pilots implementing them.

Considering the delivery phase, the pilots engaged predominantly through design development practices (36\%), followed by meeting practices $(26 \%)$ and dementia knowledge sharing and networking practices (26\%). The latter practices doubled in size in comparison to 
the early project phases. In comparison to the front-end phase, the pilots engaging with stakeholders appear to be in the decreasing end.

Considering the handover phase, the pilots engaged in more pluralistic ways.

Dementia knowledge sharing (36\%) and open days practices (35\%) showed an exponential trend. As projects approached the completion, the number of pilots reporting stakeholder facilitation via the former practice nearly tripled and more than quadrupled via the latter practice compared to the early phase. Whereas media exposure was not mentioned in the previous two phases, during handover, $32 \%$ of the pilots implemented this practice.

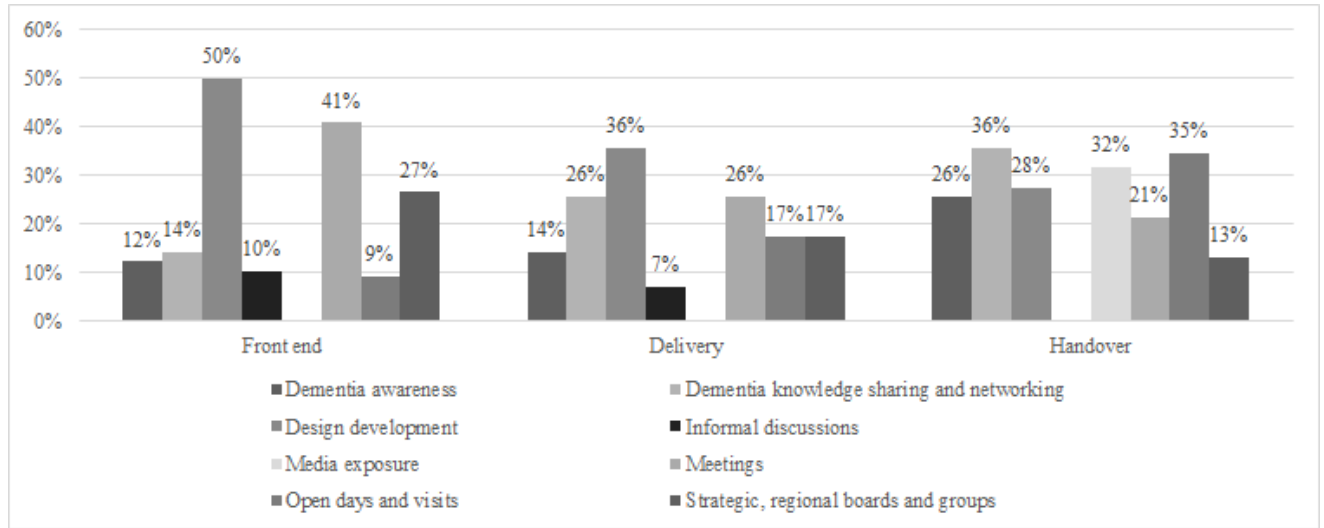

Figure 4: Percentage of pilots facilitating the eight practices across the projects' lifecycles

To determine whether there were any statistically significant differences between the means of these three phases, a repeated measures ANOVA test was performed. The null hypothesis $(\mathrm{H} 0)$ is that mean of stakeholder engagement practices is the same at all-time points. The alternative hypothesis is that mean stakeholder engagement practices is significantly different at one or more time points. Statistical analysis of the data in Table 3 shows that between the three phases, the average stakeholder engagement is not significantly different $(p=0.597)$. However, the analysis shows that there is significant within-practice variance $(\mathrm{F}=2.39, p<0.10)$. This indicates that, in each project phase, some practices were implemented by more pilots than others across the Programme. 
Table 3: Average stakeholder engagement for each phase in the NDCIP. Between the three phases, the average stakeholder engagement is not different, however, the within practice variance is significant

Repeated measures ANOVA

\begin{tabular}{lrrrrrr}
\hline \multicolumn{1}{c}{ Source of Variation } & \multicolumn{1}{c}{$S S$} & $d f$ & \multicolumn{1}{c}{$M S$} & $F$ & P-value & Fcrit \\
\hline Within-groups & 2085.167 & 7 & 297.881 & 2.393 & $0.078^{*}$ & 2.193 \\
Between-groups & 133 & 2 & 66.5 & 0.534 & 0.597 & 2.726 \\
Error & 1742.333 & 14 & 124.452 & & & \\
Total & 3960.5 & 23 & & & & \\
\hline
\end{tabular}

*Significant at $p=0.10$

\section{Which practices mostly involved external stakeholders?}

At a more detailed level, the analysis assessed which practices mostly involved external stakeholders. Figure 5 shows the percentage of pilots engaging with external stakeholders throughout the projects' lifecycles. Inspecting the projects front-end, $44 \%$ of the 98 pilots engaged external stakeholders through design development practices, followed by meetings $(38 \%)$ and dementia knowledge sharing practices (13\%). In contrast, strategic regional boards and groups practices reported a significant drop in engaging with external stakeholders with only $6 \%$ pilots including this stakeholder category in this practice.

Moving to the delivery phase, a significant drop in engagement with external stakeholders was observed. Meetings was the practice which attracted most external stakeholders (15\%), followed by dementia knowledge sharing and networking (14\%). Design development engagement and open days and visits engaged with this group at the same rate (11\%). This was a significant change for the former practice compared with the high engagement rate in the front-end phase.

Regarding the handover phase, the observations suggest the pilots increased engagement with external stakeholders. Media exposure was the most favoured practice $(32 \%)$, followed by three practices with similar ratios (dementia knowledge sharing and networking (24\%); open days and visits (22\%); and dementia awareness (19\%). These 
observations suggest the pilots employed various practices to show the outputs of their projects and report progress.

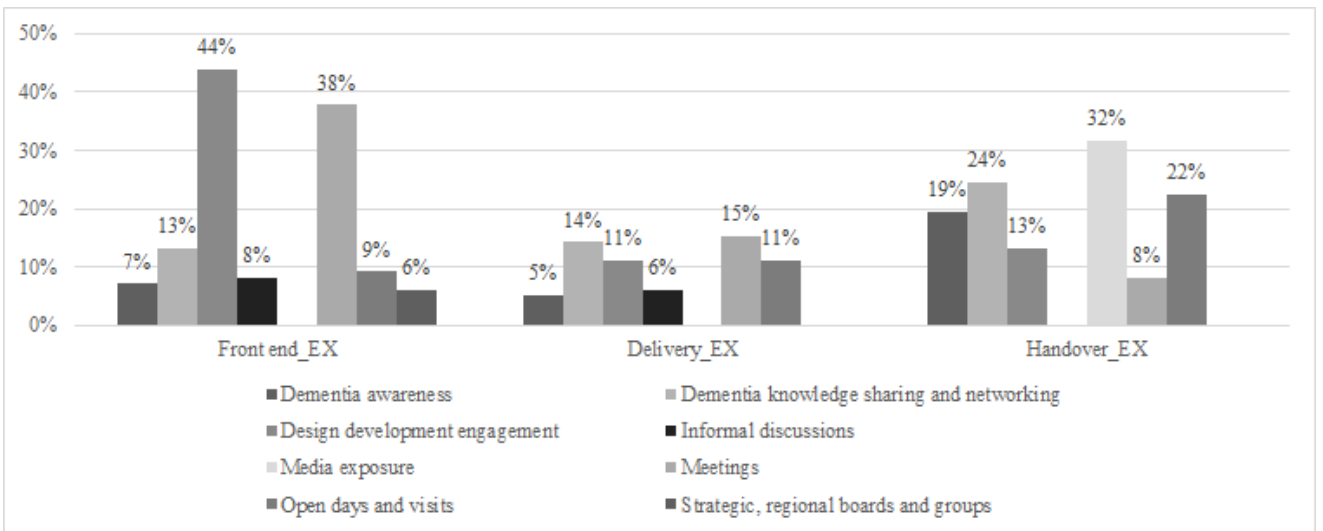

Figure 5: Percentage of pilots engaging with external stakeholders within the eight practices across the projects' lifecycles in the NDCIP

\section{Engagement and Disengagement Practices of the NDCIP}

The analysis thus far shows the practices taking place across the projects' lifecycles, the rate of pilots committing to them and furthermore, the practices engaging external stakeholders. The interplay of how external stakeholders engaged and disengaged over time is discussed in this section as well as the observed outcomes. The eight practices are positioned to show the process of engagement and disengagement across the projects' lifecycles and the rationales for the identified practices. The rationales aim to provide the dynamic motives for engagement and disengagement across the projects' lifecycles.

The results in Table 4 present the six rationales and engagement and disengagement practices supporting them. Considering the statistical findings, the practices were initially positioned as engagement based on whether they involved primarily external stakeholders (Figure 5). Conversely, the practices were positioned as disengagement when involvement of external stakeholders was low. Next, the practices were checked against the number of pilots reporting to have used them. This led to the development of clusters of practices with engagement or disengagement features. By clustering practices, representation from the 
majority of pilots was justified ${ }^{3}$. If the number of pilots reporting engagement with external stakeholders was $>50 \%$, then the cluster of practices would be classified as engagement practice cluster. Practices that were implemented by a number of pilots between $30 \%$ and $50 \%$ were classified as a mutual communication channel between the external and internal stakeholders. Finally, a cluster of practices reporting $<30 \%$ engagement was classified as disengagement cluster.

Table 4: External stakeholder engagement and disengagement practices and rationales in the NCDIP

\begin{tabular}{|c|c|c|c|}
\hline Phases & Rationales & Practices & Pilots, \% \\
\hline Front-end & $\begin{array}{l}\text { Creating trust with networks of } \\
\text { stakeholders }\end{array}$ & $\begin{array}{l}\text { - } \quad \text { Dementia knowledge } \\
\text { sharing and networking } \\
\text { - } \quad \text { Dementia awareness } \\
\text { - } \quad \text { Informal discussions } \\
\text { - } \quad \text { Open days and visits }\end{array}$ & $30 \%$ \\
\hline \multirow[t]{2}{*}{ Front-end } & $\begin{array}{l}\text { Co-creating innovative design ideas } \\
\text { (engagement) }\end{array}$ & $\begin{array}{l}\text { Design development } \\
\text { engagement } \\
\text { - Meetings }\end{array}$ & $78 \%$ \\
\hline & (disengagement) & $\begin{array}{l}\text { - Strategic regional boards } \\
\text { and groups }\end{array}$ & $7 \%$ \\
\hline Delivery & $\begin{array}{l}\text { Maintaining interaction with external } \\
\text { stakeholders to inform project progress }\end{array}$ & $\begin{array}{ll}\text { - } & \text { Informal discussions } \\
\text { - } & \text { Meetings } \\
\text { - } & \text { Open days and visits } \\
\text { - } & \text { Dementia knowledge } \\
\text { sharing and networking } \\
\text { - } & \begin{array}{l}\text { Design development } \\
\text { engagement }\end{array}\end{array}$ & $53 \%$ \\
\hline Delivery & $\begin{array}{l}\text { Creating a shared knowledge base } \\
\text { (inward) } \\
\text { (disengagement) }\end{array}$ & $\begin{array}{l}\text { - } \quad \text { Dementia awareness } \\
\text { - } \quad \text { Strategic regional boards } \\
\text { and groups }\end{array}$ & $9 \%$ \\
\hline Handover & $\begin{array}{l}\text { Knowledge sharing and formation of } \\
\text { organisational legitimacy and reputation } \\
\text { (outward) } \\
\text { (engagement) }\end{array}$ & $\begin{array}{ll}\text { - } & \text { Media exposure } \\
\text { - } & \text { Dementia knowledge } \\
& \text { sharing and networking } \\
\text { - } & \text { Open days and visits } \\
\text { - } & \text { Dementia awareness }\end{array}$ & $71 \%$ \\
\hline Handover & $\begin{array}{l}\text { Evaluating and monitoring project } \\
\text { performance and evidence }\end{array}$ & $\begin{array}{ll}\text { - } & \text { Design development } \\
\text { engagement } \\
\text { - } & \text { Meetings } \\
\text { - } & \text { Strategic regional boards } \\
\text { and groups }\end{array}$ & $29 \%$ \\
\hline
\end{tabular}

\footnotetext{
${ }^{3}$ Lehtinen et al., (2019) three 'states' of classifying practices between the engagement and disengagement spectrum was operationalised in the analysis.
} 


\section{Front-end phase}

Creating trust with networks of stakeholders

The pilots communicated with external stakeholders through four practices, which facilitated the development of a stakeholder network that was used across the projects' lifecycles. The multiplicity of practices employed in this phase ensured reaching out to a variety of both internal and external stakeholders. The development of a network aimed at collecting different views and making sure relevant stakeholders were not left out from the consultation. The most prominent stakeholder groups during the front-end phase were people LWD (81\%), family, friends and carers (77\%), and staff (54\%).

In dementia knowledge sharing practices, the pilots introduced the initiative and aimed "at making [external stakeholders] aware of the background towards the projects and the aims/objectives". Such activities affected the pilots positively regarding the content and opportunities for the proposals put forward, as perceived by the pilots. One pilot noted, "[dialogues with family members] have made an invaluable contribution to our project proposals”. In dementia awareness practices, the pilots used the Programme as an opportunity to raise awareness regarding the condition itself. They participated in campaigns such as the 'Forget Me Not Campaign' to make external stakeholders conscious about the implications of conditions such as dementia. These activities allowed the pilots "to broadly raise awareness to a number of long-term conditions". Another pilot recognised the impact this approach had not just to the built environment, but also to the dementia care provision as a whole: "we recognise that the feedback and participation of service users and carers can positively influence the delivery of health services". Open days stimulated external groups such as support networks to join the Programme effectively increasing local provision and support towards the Programme delivery. Informal discussion practices with external stakeholders influenced the course of the Programme, as one pilot put it: "their comments and 
suggestions for change [of scope] also influenced the direction of the Programme". Once the initial network of external stakeholders was developed the pilots moved to the more intensive exercise of co-creating preliminary design objectives.

Co-creating innovative design ideas

The pilots introduced the external stakeholders to design development practices and on-going meetings so both groups could co-create the design objectives. The two practices cemented external stakeholders as important contributors in the Programme. The design development practices gave the opportunity to external stakeholders to "give their input about the environmental transformation". Because of this engagement, "the final designs were open to scrutiny and feedback", as described by one pilot, which further elaborated:

"It is shown people what can be done, and how it can be done by using obviously lots of engagement and getting the right people in at the right time with upfront design rather than going pitching retrospectively because that's where the cost is in retrospective work".

Face-to-face meetings with staff were employed "asking them what they see the issues [...] were and any solutions they had". These engagements with staff resulted in pilots recognising the physical environment was not supporting the service provided. One pilot explained the result of this engagement and how it sharpened the Programme's focus: "our staff are very caring, but the environment does not match up to the high standard of care we provide. They specifically stated that they want improvements to patient privacy and dignity".

The practices blended a sense of creativity and feedback and continuous input between the two groups. This engagement cluster ensured user experience was fed into the Programme's objectives. The pilots' motivation for engagement is summed by this excerpt: "we asked how they [external stakeholders] would like to see the ward changed and how we could as an organisation improve the care for people with dementia". The pilots would keep 
accountability of the design outputs, implementing trust board meetings, strategic partnership meetings, etc. This disengagement practice ensured two things: 1) the co-created objectives were validated with internal strategic stakeholders; and 2) stayed within the Programme's timeline and budget.

\section{Delivery phase}

Maintaining interaction with external stakeholders to inform project progress

By this stage, the design was developed and agreed with external stakeholders, and the pilots were delivering the objectives agreed by both groups. Despite this phase being about the pilots undertaking construction developments, engagement with external stakeholders was significant and the most prominent groups were staff (36\%), family, friends and carers (29\%) and people LWD (28\%). The pilots utilised five diverse practices, which served to maintain interaction with external stakeholders. Informal discussions with patients enabled the pilots to record that "on average the cleanliness of the environment and easiness of navigation was noted". Meeting practices and open days brought together internal and external stakeholders to discuss and review progress of their co-created activities, but also to respond promptly to emergent issues or changes in the projects. Dementia knowledge practices included dissemination of information both about the various works such as ward redesign. These engagements resulted in "making aware of the benefits which would emerge from enhancing our environment". Design development practices were utilised to further "advise [external stakeholders] on usability and design of parts of the scheme". As a result, designers used traditional and home-like type interior design features in hospitals, "something that originally was not believed to be possible". This resulted in the built environment being: "less clinical and provides a more comfortable caring environment". The high percentage (53\%) of the sum of these practices as opposed to the smaller percentages for each practice individually, 
suggests pilots would use these as part of their portfolio engagement strategy, and practices may have been used in conjunction or as alternatives.

\section{Creating a shared knowledge base (inward)}

The disengagement activities served as vehicles for knowledge sharing inwards about the progress and approach the pilots have taken across the Programme. By disengaging, the pilots could 'pause' collaborations with external stakeholders and engage instead in 'expert' discussions with other pilots and their wider internal stakeholder teams. This way they kept in line with the Programme timeline and were able to align themselves with the rest of the pilots. Dementia awareness practices enabled sharing lessons learnt through presentations with wider internal stakeholders such as trust executive teams. This brought a cultural shift characterised by changes in attitudes, perceptions and awareness as to how people LWD should be treated and cared for. One of the pilots highlighted the broader impact of these engagements to the service: "engagement has also informed the organisation on how to further improve our level of care for people with dementia". Whilst strategic, regional boards and groups activities were more high-level discussions on improving care provision and pathway for those LWD. This disengagement with external stakeholders enabled pilots to generate positive outlook of their project to policy makers and commissioners including Councils and Boroughs.

\section{Handover phase}

Knowledge sharing and formation of organisational legitimacy and reputation (outward)

As the projects approached completion, the pilots adopted a robust outwards-facing approach. The interactions between the two stakeholder groups increased significantly. Seventy-three per cent of the pilots engaged with external stakeholders in one or more of the four engagement practices: media exposure; dementia knowledge sharing and networking; open 
days and visits; and dementia awareness practices. The rationale for these practices was for both internal and external stakeholders to show the new dementia-friendly environments they have co-created. The most prominent groups were people LWD (37\%); local communities $(34 \%)$; and staff (32\%).

Media exposure practices communicated to the wider public coordinated messages "to show a timeline of the project as potentially people can visualise the pre and post refurbishment". Dementia awareness practices, such as feedback sessions and dementia theatre workshops, resulted in "culminating in an exhibition which offered an alternative, positive view of people with dementia as creative individuals". Dementia knowledge sharing practices enabled pilots to show "the works to the general public along with other innovations we have implemented" as part of the dementia improvements that were championed. As result of the changes in the built environment, the pilots arranged sessions for staff training thus they could "help in the provision of integrated care". During open days, staff acted as ambassadors of the cultural changes brought by the Programme. One pilot summarised this outcome:

"saying to a relative about all the changes that had been made and the difference it had made to the atmosphere. The change in attitude to the elderly care wards from within the hospital has been very positive seeing them as more specialised wards".

\section{Evaluating and monitoring project performance and evidence}

The pilots evaluated and monitored projects' performance and gathered further evidence to understand the impact of this initiative. The pilots employed design development practices and facilitated research instruments, such as surveys. They also gathered feedback and made the results publicly available to highlight the positive outlook generated by the Programme. Through strategic, regional boards and groups practices, the pilots produced papers and other 
material detailing the developed proposals to internal stakeholders with interest over the Programme, such as County Councillors and MPs. The analysis of rationales and engagement and disengagement practices discussed in this section is summarised in the processual model in Figure 6. 


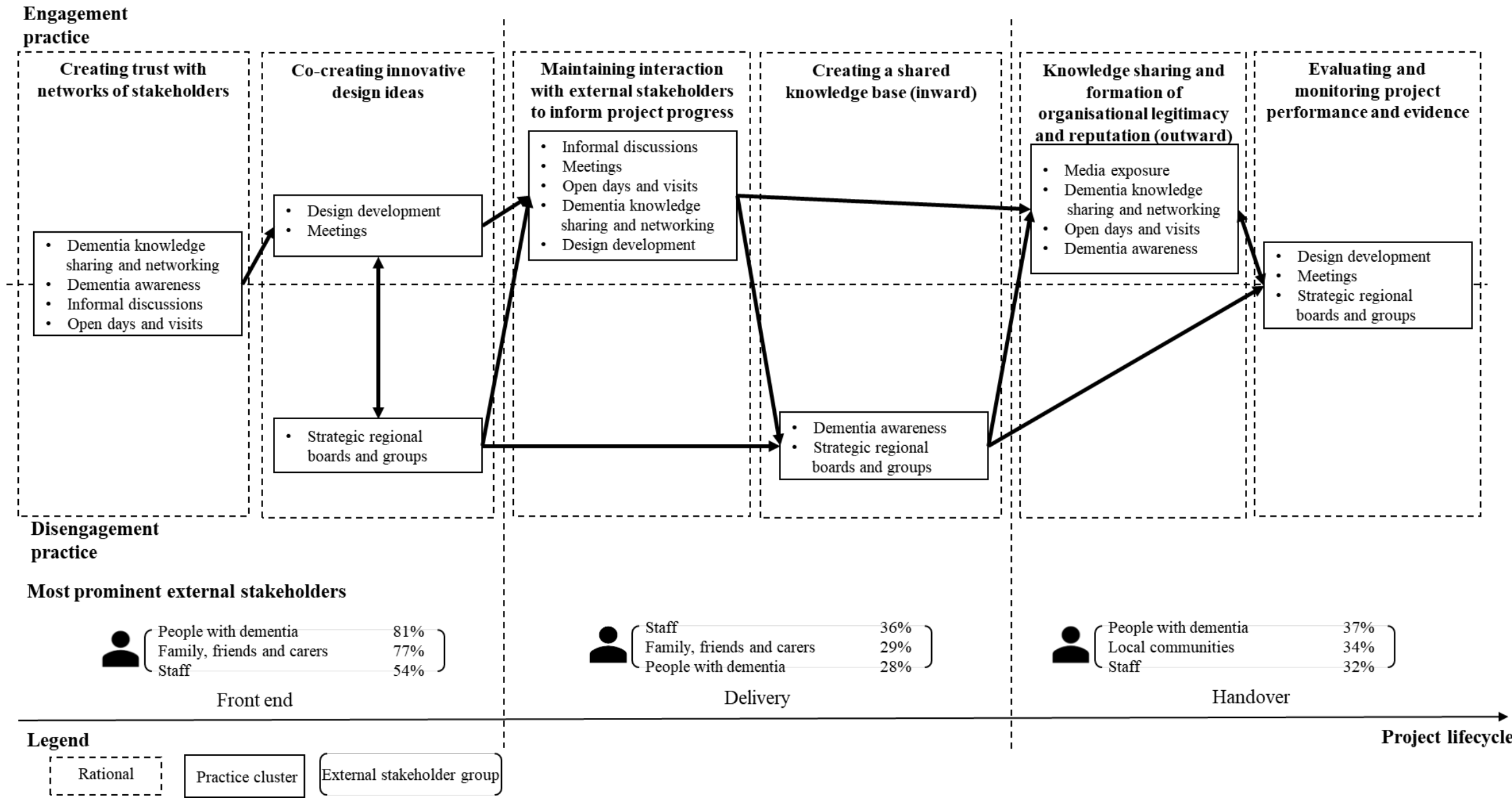

Figure 6: Rationales for engagement and disengagement in the NDCIP 


\section{Discussion}

\section{Theoretical implications}

This study unfolded the stakeholder engagement and disengagement rationales across the lifecycle of 98 projects for dementia-friendly environments. The processual model, as depicted in Figure 6, further supports existing literature (Aaltonen and Kujala, 2016) that stakeholder engagement in complex projects is dynamic. Whilst, the theoretical approach provides a novel view of stakeholder engagement that previous literature has overlooked, as engagement and disengagement processes are mainly described in static terms (Lehtinen et al., 2019). The paper provides empirical evidence to substantiate previous studies conceptual propositions, which perceive the project as an emerging network that extends and transforms over time and need longitudinal studies to be understood (Eskerod and Vaagaasar, 2014). The emergent and temporary nature of the rationales found in the NCIDP, is an example of how an emerging network extends and transforms itself throughout the project life.

The patterns of engagement and disengagement, as depicted in Figure 6, reveal that the pilots implemented a cyclical strategy with recurring use of engagement and disengagement practices. In this way, pilots were able to combine long-term value achievements, which were aligned with external stakeholders' interests (Chan and Oppong, 2017) with short-term project specific goals (Aaltonen and Kujala, 2010, Flyvbjerg, 2014). This is in accordance with Lehtinen et al., (2019), who explained that engagement and disengagement practices cycle back and forth between the two to achieve systemic outcomes. However, in contrast to Lehtinen et al., (2019), who presented a limited array of cycling practices, those employed in the NDCIP followed also a recurring pattern, with a large range of practices working in clusters. This indicates the pilots employed a pluralist approach to engage with diverse groups of external stakeholders. The recurring character of the practices enabled the pilots to achieve economies of repetition. 
Furthermore, this study explicates the outcomes of these practices, which suggest that the pilots engaged in a collaborative approach (Tee et al., 2019) with external stakeholders. In contrast to previous views that see engagement approaches as dependent on the attributes of the stakeholders involved (Dunham et al., 2006), and provide a simplistic connotation to engagement and disengagement as positive or negative (Aaltonen et al., 2015), this study suggests that a collaborative approach consists of engagement and disengagement practices, and mutual communication channels. Whilst the mutual communication channels are essential in the creation of stakeholder networks, the engagement practices endorse a notion of collaboration amongst all parties and the disengagement practices ensure project deliverability, which is in accordance with previous studies (Aaltonen and Kujala, 2010, Flyvbjerg, 2014).

In contrast to project management literature, which regards external stakeholders and their actions in negative and opposing terms, and network-level approach as a challenge to reach project objectives (Flyvbjerg 2014, Di Maddaloni and Davis, 2018), the pilots demonstrated that large-scale dynamic engagement is possible, even with vulnerable groups such as people LWD. This was achieved by planning multiple practices able to suit the interests and the ability of different stakeholders (e.g. fieldwork approach and experiencebased design to engage with people LWD). Notable studies termed stakeholder engagement as a dynamic process that changes over time and focused on external stakeholders, such as community groups, lobbyists, environmentalists and other non-governmental organisations, who "oppose the project and whose interests differ from those of the project" (Aaltonen and Kujala, 2010). Conversely, in the current study the external stakeholders involved in the Programme presented a constructive attitude towards it. This is because their actions were not driven by concerns (Chan and Oppong, 2017), but by interests aligned with the long-term values of the Programme (see Table 1). In fact, no adversarial relationships were recorded in 
any of the 98 reports that were analysed. For these reasons, the common negative connotation to disengagement practices, presented in the project management literature, is not present in this context. This is because stakeholder management was not implemented to handle conflicts but to create value and through engagement and disengagement practices, it was possible for internal and external stakeholders to achieve effective collaboration.

\section{Managerial implications}

The perspective offered by this study has significant implications for practicing managers, suggesting their projects can benefit from adopting timely engagement and disengagement practices throughout the project lifecycle. Facilitation of and between engagement and disengagement practices requires a certain degree of flexibility from a management point. As practices flow between engagement and disengagement clusters, it requires a certain capability of coordination to know when to switch. The 'switch point' is linked to the rationales, which the practices correspond to. It is recommended that stakeholder management approaches with easily reachable switch points would be more balanced than approaches with more remote switch points. How managers decide to switch from engagement to disengagement practices is dependent on the type of rational these practices serve. Some rationales will predominantly be consisting of engagement practices and some rationales of disengagement practices. In this scenario, it is straightforward to know how and when one needs to switch e.g. from engagement to disengagement. A limitation still exists in the scenario that a rationale consists of both engagement and disengagement practices. Thus, further research could address this limitation.

\section{Conclusions}

Current research on dementia-friendly environments has focused on advancing design solutions, whilst the management of stakeholders has received less attention. Recent thinking 
in stakeholder management suggests that to achieve project systemic outcomes, it is important to timely engage and disengage external stakeholders. However, research on this topic is limited. Therefore, the aim of this paper was to provide a detailed account of the practices employed to engage and disengage external stakeholders during project lifecycle in the context of dementia-friendly environments, studying a wide range of 98 projects involved in the NDCIP. A set of comparative cases were used to investigate the dynamism of conducting engagement and disengagement practices, the rationales behind them and their outcomes. This paper reported six rationales and eight recurring practices that occur during project lifecycles. The patterns of engagement and disengagement presented in this research reveal that the pilots implemented a cyclical strategy with recurring use of engagement and disengagement practices Specifically, from a stakeholder management view, previous research associated collaborative approaches with engagement practices, whereas in practice, this research found that disengagement practices also exist and play an important role in a dynamic stakeholder management process.

The limitations of this study are bounded to the context and scale of the NDCIP. The findings might be relevant to the development of physical assets of soft infrastructure systems and might not be generalisable to projects in different settings. Therefore, more practisebased research is need in different contexts to provide further insights on effective, dynamic engagement and disengagement strategies and elucidate how, why and when disengagement practices emerge, as well as the outcomes they bring to the network.

\section{Reference list}

Aaltonen, K. and Kujala, J., 2010. A project lifecycle perspective on stakeholder influence strategies in global projects. Scandinavian Journal of Management, 26(4), 381-397. DOI: 10.1016/j.scaman.2010.09.001.

Aaltonen, K. and Kujala, J., 2016. Towards an improved understanding of project stakeholder landscapes. International Journal of Project Management, 34(8), 15371552. DOI: 10.1016/j.ijproman.2016.08.009. 
Aaltonen, K., Kujala, J., Havela, L. and Savage, G., 2015. Stakeholder dynamics during the project front-end: the case of nuclear waste repository projects. Project Management Journal, 46(6), 15-41. DOI: 10.1002/pmj.21549.

Aaltonen, K. and Sivonen, R., 2009. Response strategies to stakeholder pressures in global projects. International Journal of Project Management, 27(2), 131-141.

DOI: 10.1016/j.ijproman.2008.09.007

Aarikka-Stenroos, L., Jaakkola, E., Harrison, D. and Mäkitalo-Keinonen, T., 2017. How to manage innovation processes in extensive networks: A longitudinal study. Industrial Marketing Management, 1-18. DOI: 10.1016/j.indmarman.2017.09.014

Aarts, M.M., et al., 2015. Dynamic lighting systems in psychogeriatric care facilities in the Netherlands: a quantitative and qualitative analysis of stakeholders' responses and applied technology. Indoor and built environment, 24(5), 617-630. doi: $10.1177 / 1420326$ X1453238

Bal, M., Bryde, D., Fearon, D. and Ochieng, E., 2013. Stakeholder Engagement: Achieving Sustainability in the Construction Sector. Sustainability, 5(2), 695-710. DOI: $10.3390 /$ su5020695.

Bourne, L. and Walker, D.H.T., 2005. Visualising and mapping stakeholder influence. Management Decision, 43(5), 649-660. DOI: 10.1108/00251740510597680.

Casidy, R., Helmi, J. and Bridson, K., 2019. Drivers and inhibitors of national stakeholder engagement with place brand identity. European Journal of Marketing. 1-21. DOI: $10.1108 /$ EJM-04-2017-0275

Chan, A.P.C. and Oppong, G.D., 2017. Managing the expectations of external stakeholders in construction projects. Engineering Construction \& Architectural Management, 24(5), 736-756. DOI: 10.1108/ECAM-07-2016-0159.

Chinyio, E. and Akintoye, A., 2008. Practical approaches for engaging stakeholders: findings from the UK. Construction Management and Economics, 26(6). 591-599. DOI: $10.1080 / 01446190802078310$

Cleland, D.I., 1986. Project stakeholder management. Project Management Journal, 17(4), $36-44$.

Collinge, W.H. and Harty, C.F., 2014. Stakeholder interpretations of design: Semiotic insights into the briefing process. Construction Management and Economics, 32(7-8), 760-772. DOI: 10.1080/01446193.2014.894247.

Collinge, B., 2016. Stakeholder management strategies during construction project work. British Journal of Health Care Management, 22 (8), 394-400. DOI: 10.12968/bjhc.2016.22.8.394.

DH, 2013. Dementia: A state of the nation report on dementia care and support in England. Norwich, UK: The Stationery Office Limited on behalf of the Controller of Her Majesty's Stationery Office.

Di Maddaloni, F. and Davis, K., 2017. The influence of local community stakeholders in megaprojects: Rethinking their inclusiveness to improve project performance. International Journal of Project Management, 35(8), 1537-1556. DOI: 10.1016/j.ijproman.2017.08.011.

Di Maddaloni, F. and Davis, K., 2018. Project manager's perception of the local communities' stakeholder in megaprojects. An empirical investigation in the UK. International Journal of Project Management, 36(3), 542-565. DOI: 10.1016/j.ijproman.2017.11.003.

Dunham, L., Freeman, R. E. and Liedtka, J., 2006. Enhancing stakeholder practice: A particularized exploration of community. Business Ethics Quarterly, 16(1), 23-42. DOI: $10.5840 /$ beq20061611. 
Edkins, A., Geraldi, J., Morris, P. and Smith, A., 2013. Exploring the front-end of project management. Engineering Project Organization Journal, 3(2), 71-85.

DOI: $10.1080 / 21573727.2013 .775942$.

Elliott, J., Mcneil, H., Ashbourne, J., Huson, K., Boscart, V. and Stolee, P., 2016. Engaging Older Adults in Health Care Decision-Making: A Realist Synthesis. The patient, 9(5), 383-393. DOI: 10.1007/s40271-016-0168-x.

Eskerod, P. and Huemann, M., 2014. Managing for stakeholders. In J. R. Turner (Ed.), Gower handbook of project management (5th ed.). Aldershot, England: Gower.

Eskerod, P., Huemann, M. and Ringhofer, C., 2015. Stakeholder inclusiveness: Enriching project management with general stakeholder theory. Project Management Journal, 46(6), 42-53. DOI: 10.1002/pmj.21546.

Eskerod, P. and Vaagaasar, A.L., 2014. Stakeholder management strategies and practices during a project course. Project Management Journal. 45(5), 71-85.

DOI: $10.1002 / \mathrm{pmj} .21447$.

Field, A., 2009. Discovering statistics using SPSS. 3. ed., reprint. Los Angeles: SAGE.

Fleming, R. and Purandare, N., 2010. Long-term care for people with dementia: environmental design guidelines, International Psychogeriatrics, 22(7), 1084-1096. DOI: $0.1017 / \mathrm{S} 1041610210000438$.

Flyvbjerg, B., 2014. What you should know about megaprojects and why: An overview. Project Management Journal, 45(2), 6-19. DOI: 10.1002/pmj.

Greenwood, M., 2007. Stakeholder engagement: beyond the myth of corporate responsibility. Journal of Business Ethics. 74(4), 315-327. DOI: 10.1007/s10551-007-9509-y.

Gulati, R., Wohlgezogen, F. and Zhelyazkov, P., 2012. The two facets of collaboration: Cooperation and coordination in strategic alliances. The Academy of Management Annals, 6(1), 531-583. DOI: 10.1080/19416520.2012.691646

Hellström, I., Nolan, M., Nordenfelt, L. and Lundh, U., 2007. Ethical and methodological issues in interviewing persons with dementia. Nursing Ethics, 14(5), 608-619. DOI: $10.1177 / 0969733007080206$.

Jenkins, B.R., 2018. Socio-economic Issues and Collaborative Governance. In: Water Management in New Zealand's Canterbury Region. Global Issues in Water Policy, vol 19. Springer, Dordrecht.

Jergeas, G. F., et al., 2000. Stakeholder management on construction projects. AACE international transactions, 12, 1-5.

Larson, E.B., Yaffe, K. and Langa, K.M., 2013. New insights into the dementia epidemic. The New England journal of medicine, 369(24), 2275. DOI: 10.1056/NEJMp1311405.

Lehtinen, J., Aaltonen, K. and Rajala R., 2019. Stakeholder management in complex product systems: Practices and rationales for engagement and disengagement. Industrial Marketing Management. 79, 58-70. DOI: 10.1016/j.indmarman.2018.08.011.

Meynhardt, T., Chandler, J.D. and Strathoff, P, 2016. Systemic principles of value cocreation: Synergetics of value and service ecosystems. Journal of Business Research, 69(8), 2981-2989. DOI: 10.1016/j.jbusres.2016.02.031.

Miles, S. J., 2012. Stakeholder: Essentially Contested or Just Confused? Journal of Business Ethics, 108(3), 285-298. DOI: 10.1007/s10551-011-1090-8.

Missonier, S. and Loufrani-Fedida, S., 2014. Stakeholder analysis and engagement in projects: From stakeholder relational perspective to stakeholder relational ontology. International Journal of Project Management, 32(7), 1108-1122. DOI: 10.1016/j.ijproman.2014.02.010.

Mitchell, R.K., Agle, B.R. and Wood, D.J., 1997. Toward a theory of stakeholder identification and salience: defining the principle of who and what really counts. The Academy of Management Review, 22(4), 853-886. DOI: 10.2307/259247. 
Mok, K.Y., Shen, G.Q. and Yang, J., 2015. Stakeholder management studies in mega construction projects: a review and future directions. International Journal of Project Management. 33(2), 446-457. DOI: 10.1016/j.ijproman.2014.08.007.

Morris, P.W., 2013. Reconstructing project management. US: John Wiley \& Sons.

Moskowitz, D.S., 1986. Comparison of self-reports, reports by knowledgeable informants, and behavioral observation data. Journal of personality, 54(1), 294-317.

Muller, R., 2009. Project Governance. London: Gower Publishing, Ltd.

Olander, S. and Landin, A., 2005. Evaluation of stakeholder influence in the implementation of construction projects. International Journal of Project Management, 23(4), 321-328. DOI: 10.1016/j.ijproman.2005.02.002.

Pantzartzis, E., Price, A.D.F. and Pascale, F., 2016. A built environment response to the rising costs of dementia. Journal of Financial Management of Property and Construction, 21(2), 160-187. DOI: 10.1108/JFMPC-06-2015-0019.

Parmar, B., Freeman, R., Harrison, J., Wicks, A., Purnell, L. and De Colle, S., 2010. Stakeholder theory: The state of the art. Academy of Management Annals, 4(1), 403445. DOI: $10.1080 / 19416520.2010 .495581$.

Paulhus, D.L. and Vazire, S., 2007. The self-report method. Handbook of research methods in personality psychology, 1, pp.224-239. New York: Guilford

Pentland, B.T., 1999. Building process theory with narrative: From description to explanation. Academy of management Review, 24(4), 711-724.

Post, J. E., Preston, L. E., and Sachs, S., 2002. Redefining the corporation. Stanford, CA: Stanford Business Books.

Project Management Institute, 2013. A Guide to the Project Management. Body of Knowledge (PMBoK Guide). Fifth ed. Project Management Institute, Newtown Square, PA, USA.

Post, J.E., Preston, L.E. and Sachs, S., 2002. Redefining the corporation. Stanford, California: Stanford Business Books.

Rampersad, G., Quester, P. and Troshani, I., 2010. Managing innovation networks: Exploratory evidence from ICT, biotechnology and nanotechnology networks. Industrial Marketing Management, 39(5), 793-805.

DOI: 10.1016/j.indmarman.2009.07.002.

Reypens, C., Lievens, A. and Blazevic, V., 2016. Leveraging value in multi-stakeholder innovation networks: A process framework for value co-creation and capture. Industrial Marketing Management, 56, 40-50. DOI: 10.1016/j.indmarman.

Tee, R., Davies, A. and Whyte, J., 2019. Modular designs and integrating practices: Managing collaboration through coordination and cooperation. Research Policy, 48(1), 51-61. DOI: 10.1016/j.respol.2018.07.017.

Teo, M. and Loosemore, M., 2017. Understanding community protest from a project management perspective: A relationship-based approach. International Journal of Project Management, 35(8), 1444-1458. DOI: 0.1016/j.ijproman.2017.08.004.

Vaagaasar, A.L., 2011. Development of relationships and relationship competencies in complex projects. International Journal of Managing Projects in Business, 4(2), 294-307. DOI: $10.1108 / 17538371111120252$

van Hoof, J.J. and Verkerk, M.M., 2013. Developing an integrated design model incorporating technology philosophy for the design of healthcare environments: a case analysis of facilities for psychogeriatric and psychiatric care in The Netherlands. Technology in Society, 35(1), 1-13. DOI: 10.1016/j.techsoc.2012.11.002.

Winch, G.M., Morris, P. and Pinto, J., 2007. Managing project stakeholders. In: Peter W. G. Morris, P. W. G., Pinto, J. K., eds. 2010 The Wiley guide to project, program, and portfolio management, US: John Wiley \& Sons. pp.271-289. 
Windsor, D., 2010. The role of dynamics in stakeholder thinking. Journal of Business Ethics. 96(1), 79-87. DOI: 10.1007/s10551-011-0937-3.

World Health Organization (WHO), 2015. World report on ageing and Health. [online] WHO. Available from: https://www.who.int [Accessed 2 August 2017]. 